\title{
Medusae and ctenophores from the Bahía Blanca Estuary and neighboring inner shelf (Southwest Atlantic Ocean, Argentina)
}

\author{
M. Sofía Dutto ${ }^{1,2^{*}}$, Gabriel N. Genzano ${ }^{1,3,4}$, Agustín Schiariti ${ }^{1,3,5}$, Julieta Lecanda ${ }^{6,7}$, Mónica S. Hoffmeyer ${ }^{1,2,8}$ \\ and Paula D. Pratolongo 1,2,9
}

\begin{abstract}
An updated checklist of medusae and ctenophores is presented for the first time for the area comprised by the Bahia Blanca Estuary, the adjacent shelf El Rincón and Monte Hermoso beach, on the southwest coast of Buenos Aires province (Argentina). The area is highly productive and provides several ecosystem services including fishing and tourism. Updated information on the biodiversity of medusae and ctenophores species is essential for the study area, given that these species can affect ecosystem services. The list includes 23 hydromedusae, 3 scyphomedusae, and 3 ctenophores. Five hydromedusae (Halitiara formosa, Amphinema dinema, Aequorea forskalea, Clytia lomae and Halopsis ocellata) were firstly observed in this area. Three species of medusae, 2 hydromedusae (Olindias sambaquiensis and Liriope tetraphylla) and 1 scyphomedusae (Chrysaora lactea) pose a potential health risk, due to their toxicity to humans. Considering the size of the study area, the Bahía Blanca region has a comparatively high species richness of hydromedusae, higher than larger zones previously studied along the temperate SW Atlantic Ocean. The present report provides the baseline knowledge of gelatinous species for the Bahía Blanca region.
\end{abstract}

Keywords: Gelatinous species, Composition, Richness, Coastal ecosystem, South America

\section{Introduction}

Our knowledge of gelatinous fauna (medusae and ctenophores particularly) in the Argentine Sea has been much enhanced since major contributions by Ramírez and Zamponi (1981), Bouillon (1999), Mianzan (1999), Mianzan and Cornelius (1999), Genzano et al. (2008a) and Rodriguez (2012). However, the Bahía Blanca Estuary and its neighboring inner shelf is a still largely understudied area, in spite of the widely recognized ecosystem services that these coastal waters provide, such as wildlife support (Delhey and Petracci 2004; Hoffmeyer et al. 2009; Guinder et al. 2013) and fisheries production (Carozza and Fernández Aráoz 2009), as well as nutrient cycling and amelioration of heavy metal pollution (Negrin et al. 2016). These coastal waters are intensely used for fishing, recreational

\footnotetext{
* Correspondence: msdutto@criba.edu.ar

${ }^{1}$ Consejo Nacional de Investigaciones Científicas y Técnicas (CONICET), Av. Rivadavia 1917, C1033AAJ Ciudad Autónoma de Buenos Aires, Argentina ${ }^{2}$ Instituto Argentino de Oceanografía (IADO-CONICET/UNS), Área Oceanografía Biológica, La Carrindanga km 7.5, B8000FWB Bahía Blanca, Argentina

Full list of author information is available at the end of the article
}

purposes, and provide space for industrial, port and commercial activities (Acha et al. 2004; Pizarro and Piccolo 2008). Several species of medusae and ctenophores have been reported in the region (Ramírez and Zamponi 1980; Hoffmeyer and Mianzan 2004), including species which may exert considerable predation pressure on fishing resources, mainly through consumption of larvae and juveniles, as well as competition for food (Mianzan and Sabatini 1985; Mianzan 1986a; Hoffmeyer 1990). Medusae species of public health concern such as Olindias sambaquiensis and Liriope tetraphylla have also been reported in high concentrations (Mianzan and Ramírez 1996; Mianzan et al. 2000, 2001). Species composition and ecological studies on medusae and ctenophores in the Bahía Blanca region were mainly conducted in the 1980's (Mianzan and Sabatini 1985; Zamponi and Mianzan 1985; Mianzan 1986a, 1986b, 1989a, 1989b, 1989c; Mianzan and Zamponi 1988; Hoffmeyer 1990), but discontinued afterwards.

Given the potential impacts of gelatinous species on valuable ecosystem services, updated information on their biodiversity in the study area is essential. This work 
aims at compiling information on the species composition of medusae and ctenophores in the Bahía Blanca Estuary and its neighboring inner shelf. To do so, we considered earlier faunal lists and own unpublished data from plankton surveys.

\section{Materials and methods}

\section{Study area}

The study area is located in a temperate, semiarid zone in the southwestern Atlantic, Argentina $\left(38^{\circ} 30^{\prime}-41^{\circ} \mathrm{S}\right.$, $\sim 60^{\circ} \mathrm{W}$ ) (Fig. 1). According to the biogeographic division of the Argentine Sea based on its marine fauna (Balech and Ehrlich 2008), the study area represents the transition between the Rionegrine and Uruguayan Districts of the Argentine Province. In this work, we considered information on the biodiversity of medusa and ctenophore species from the Bahía Blanca Estuary (BBE), the associated sandy beaches of Monte Hermoso (MH) located north of the estuary, and the adjacent shelf El Rincón (ER) (Fig. 1). The BBE is a shallow, funnel shaped system, oriented NW/SE. The estuarine area comprises a dense arrangement of meandering channels and islands, surrounded by extensive intertidal mudflats and marshes (Pratolongo et al. 2013). The inner zone of the estuary is characterized by a shallow ( $\sim 7 \mathrm{~m}$ depth) and vertically homogeneous water column, due to the strong tidal mixing and wind forcing (Popovich and Marcovecchio 2008). Turbidity and nutrient contents are typically high, with a strong seasonal pattern (Popovich and Marcovecchio 2008). ER, in the adjacent shelf, extends to the $50 \mathrm{~m}$ isobath (Acha et al. 2004). Within the ER area, low-salinity waters and sediments from the continent (Río Negro, Río Colorado and BBE), highly saline waters from the south (San Matías Gulf) and shelf waters of typically intermediate salinity combine to create oceanic fronts and circulation cells that favor retention mechanisms, creating an appropriate environment for successful larval fish development (Hoffmeyer et al. 2009; Acha et al. 2012; Delgado et al. 2015). Sandy beaches of MH and Pehuen Có are one of the most visited touristic destinations of Argentina (Vaquero et al. 2007). These beaches are transitional environments between estuarine shorelines and open beaches of Buenos Aires Province (Carcedo et al. 2015; Menéndez et al. 2016), and commonly receive significant amounts of estuarine sediments (Delgado et al. 2016).

\section{Own data collection and literature review}

We present own data from 89 plankton samples, collected in 33 sampling campaigns. Plankton sampling

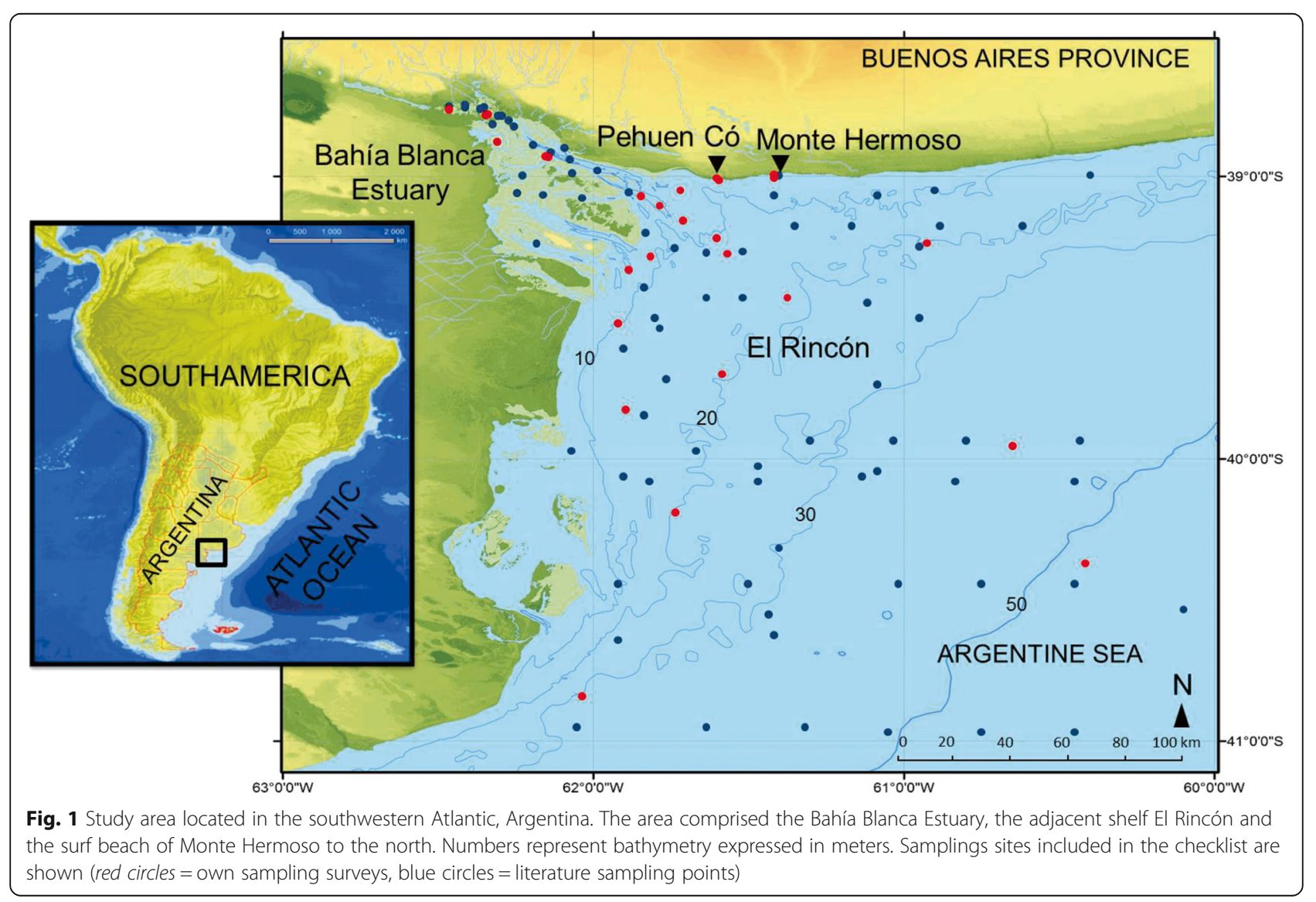


within the study area was performed in December 2012, and recurring monthly campaigns were carried out from April 2013 to May 2014, and from December 2014 to February 2015 (Fig. 1). To collect the samples, Hensen-like zooplankton nets were used (mouth diameters 30 and $40 \mathrm{~cm}$, and mesh sizes 67, 200 and $500 \mu \mathrm{m}$ ) and also a modified RMT (Rectangular Midwater Trawl; mouth opening $2.25 \mathrm{~m}^{2}$ and mesh size 1000), designed to capture a wider size range of gelatinous organisms. Hensen nets were used in oblique tows (bottom to surface) from a motorboat or ship moving at $\sim 2$ knots, during $7 \mathrm{~min}$. The RMT net was deployed against the ebb tide current, during $20 \mathrm{~min}$. Records of stranded individuals were also considered.

Gelatinous species were fixed using a solution of $4 \%$ formaldehyde in seawater and later identified following Mayer (1910), Kramp (1961), Bouillon (1999), Mianzan (1999), Mianzan and Cornelius (1999) and Bouillon et al. (2006). When necessary, the hydrozoan collection stored at the J. J. Nágera Biological Station (Universidad Nacional de Mar del Plata, Argentina) was consulted. Species which do not tolerate fixation (as the ctenophore Mnemiopsis leidyi) were immediately identified after capture. Photographic records of the collected species were obtained with a digital camera attached to a stereomicroscope, before their deposit in the Instituto Argentino de Oceanografia (IADO-CONICET). The bibliographical review was based on an exhaustive analysis of the regional literature on zooplankton published since the first scientific contributions in the 1970's until 2015, including technical reports, $\mathrm{PhD}$ and Ms Thesis (Table 1).

\section{Results}

\section{Species composition, richness and current observations}

In all, 29 species were either found in our samples or reported by others in the study area (26 of Medusozoa and 3 of Ctenophora; Table 1). Among these, 16 species (55.2\% of all gelatinous species) were recorded in our samples and also in the literature, eight species (27.6\%) were only found cited in the literature, but they did not appear in our samples, and the remaining five species (17.2\%) were found exclusively in our samples (Table 1).

Within Medusozoa, 23 species belong to the class Hydrozoa (88.5\% of Medusozoa), distributed among the orders Anthomedusae (26\%), with six families and six genera, Leptomedusae (52.2\%), with five families and 12 genera, Limnomedusae (13\%), with one family and three genera, and Trachymedusae (8.7\%), with two families and two genera. Three of the species reported in Table 1, Proboscidactyla mutabilis, Mitrocomella frigida and Olindias sambaquiensis are considered endemic to the southwestern Atlantic. Species identified to genus level only included Obelia spp. (Hydrozoa, Leptothecata), for which medusa specimens cannot be reliably determined down to species level (Bouillon et al. 2006). However, when hydroids were found at the time of medusae, the nominal species $O$. longissima, $O$. dichotoma and $O$. bidentata were cited for the study area. Five hydrozoan species (2 Anthomedusae and 3 Leptomedusae), collected in our samples, were reported for the first time in the study area: Halitiara formosa (Fewkes 1882), Amphinema dinema (Péron and Lesueur, 1810), Aequorea forskalea (Péron and Lesueur 1810), Clytia lomae (Torrey 1909) and Halopsis ocellata (Agassiz, 1865) (Fig. 2). Their taxonomic descriptions are provided below. The record of $H$. ocellata in $\mathrm{MH}$ is, as far as we know, the northern record for the Southwestern Atlantic. With respect to A. forskalea, large numbers of adult and juvenile specimens were commonly observed in $\mathrm{MH}$, either stranded on the beach or in coastal waters, during January 2014, and the massive occurrence repeated in February 2016.

Scyphozoa was represented by three species of the order Semaeostomeae, families Pelagiidae, Ulmaridae and Cyaneidae. Chrysaora lactea, Aurelia aurita and Drymonema gorgo were the only scyphozoans recorded in the area (Table 1). We did not find A. aurita ephyrae in our samples, although the use of this coastal area as a reproduction site had been suggested (Mianzan 1986a). Regarding C. lactea, ephyrae of this species were frequently found in our samples, mainly in BBE and ER.

The Phylum Ctenophora was represented by three species of the orders Lobata, Cydippida and Beroida (cf. Table 1). Mnemiopsis leidyi was found throughout the year, with higher concentrations during autumn and spring, mainly in channels within the BBE connected with island zones. Beroe ovata was also found in the estuary almost all year round, and aggregations of Pleurobrachia pileus were observed in the inner estuary during early spring.

Finally, three stinging species of public health concern were found in the area: the hydromedusae Olindias sambaquiensis and Liriope tetraphylla, and the scyphomedusa Chrysaora lactea. Regarding stinging species, a consistent summer trend was observed since 2013, characterized by decreasing numbers of $O$. sambaquiensis, and large amounts of L. tetraphylla (from 600 to more than 1000 ind. $\mathrm{m}^{-3}$ ).

\section{Taxonomic descriptions of the species observed for the first time in the study area Halitiara formosa Fewkes 1882}

Umbrella about $3 \mathrm{~mm}$ high, pear-shaped, with solid apical projection about half as long as bell cavity, 4 straight radial canals; 4 long, hollow perradial marginal tentacles and 24-35 short, solid cirrus-like tentacles; mouth simple, cruciform; with or without mesenteries; "gonads" interradial, smooth, sometimes extending over mesenteries; without ocelli; cnidome, when known, with merotrichous isorhizae (Bouillon 1999; Bouillon et al. 2006) (Fig. 2 A). 
Table 1 Review of medusae and ctenophores from the Bahía Blanca region (Argentina) based on own data and literature data. In each case, data related to study area and type of collection from own samples are highlighted in bold while those from literature are not highlighted; when both sources overlap, data are italic

\begin{tabular}{|c|c|c|c|c|}
\hline Taxa & Sampling date & Study area & Source & $\begin{array}{l}\text { Type of } \\
\text { collection }\end{array}$ \\
\hline \multicolumn{5}{|l|}{ Phylum CNIDARIA } \\
\hline \multicolumn{5}{|l|}{ Class HYDROZOA } \\
\hline \multicolumn{5}{|l|}{ Subclass HYDROIDOLINA } \\
\hline \multicolumn{5}{|l|}{ Order ANTHOATHECATA } \\
\hline \multicolumn{5}{|l|}{ Suborder FILIFERA } \\
\hline \multicolumn{5}{|l|}{ Family OCEANIIDAE } \\
\hline Turritopsis nutricula & 1979-1981; 1983-2008; 2010; 2013-2014 & $B B E-E R-\mathbf{M H}$ & $\begin{array}{l}\text { Hoffmeyer 1983; Ramírez } \\
\text { and Zamponi } \\
\text { 1980; Genzano et al. 2008a; } \\
\text { Rodriguez 2012; This study }\end{array}$ & $\mathbf{J}, A$ \\
\hline \multicolumn{5}{|l|}{ Family PANDEIDAE } \\
\hline Amphinema dinema $a^{a}$ & $2013 ; 2015$ & ER-MH & This study & A \\
\hline \multicolumn{5}{|l|}{ Family PROBOSCIDACTYLIDAE } \\
\hline Proboscidactyla mutabilis & 1970; 1983-2008 & ER & $\begin{array}{l}\text { Ramírez and Zamponi 1980; Genzano } \\
\text { et al. 2008a; Rodriguez } 2012\end{array}$ & A \\
\hline \multicolumn{5}{|l|}{ Family PROTIARIDAE } \\
\hline Halitiara formosa $a^{a}$ & 2013-2014 & ER-MH & This study & $J, A$ \\
\hline \multicolumn{5}{|l|}{ Suborder APLANULATA } \\
\hline \multicolumn{5}{|l|}{ Family CORYMORPHIDAE } \\
\hline Conymorpha januarii & 1982; 1983-2008; 2010; 2013-2014 & $B B E-E R$ & $\begin{array}{l}\text { Genzano et al. 2009a; Rodriguez } \\
\text { 2012; This study }\end{array}$ & $H^{c}, J, A$ \\
\hline \multicolumn{5}{|l|}{ Family TUBULARIIDAE } \\
\hline Hybocodon chilensis & 1983-2008; 2010 & BBE-ER & $\begin{array}{l}\text { Genzano et al. 2008a; Rodriguez } \\
\text { 2012; Rodriguez et al. } 2012\end{array}$ & $J, A$ \\
\hline \multicolumn{5}{|l|}{ Order LEPTOTHECATA } \\
\hline \multicolumn{5}{|l|}{ Family AEQUOREIDAE } \\
\hline Aequorea forskalea ${ }^{a}$ & 2014 & MH & This study & $J, A$ \\
\hline \multicolumn{5}{|l|}{ Family CAMPANULARIIDAE } \\
\hline Clytia gracilis & 1971-1972; 1997; 1998; 2003; 2013-2014 & BBE-ER-MH & $\begin{array}{l}\text { Bastida and Torti 1971; Bastida et al. } \\
\text { 1977; Genzano et al. 2009b; } \\
\text { Rodriguez 2012; This study }\end{array}$ & $H, A$ \\
\hline Clytia hemisphaerica & 1983-2008; 2010; 2014 & ER-MH & $\begin{array}{l}\text { Genzano et al. 2009b; Rodriguez } \\
\text { 2012; This study }\end{array}$ & $\mathrm{H}, \mathrm{A}$ \\
\hline Clytia lomae $e^{a}$ & 2014 & MH & This study & A \\
\hline Clytia simplex & 1970 & ER & Ramírez and Zamponi 1980 & A \\
\hline Obelia spp. & 1979-1981; 1993-2006; 2013-2014 & $B B E-E R-M H$ & $\begin{array}{l}\text { Hoffmeyer 1983; Blanco 1994; Hoffmeyer } \\
\text { and Barría de Cao 2007; Genzano et al. } \\
\text { 2008b; Genzano et al. 2009b; } \\
\text { Rodriguez 2012; This study }\end{array}$ & $H, J, A$ \\
\hline \multicolumn{5}{|l|}{ Family EIRENIDAE } \\
\hline Eutonina scintillans & 2006 & ER & Rodriguez et al. 2007 & A \\
\hline \multicolumn{5}{|l|}{ Family LOVENELLIDAE } \\
\hline Eucheilota ventricularis & 1983-2008;2010; 2013-2014 & BBE-ER-MH & $\begin{array}{l}\text { Rodriguez 2006; Rodriguez } \\
\text { 2012; This study }\end{array}$ & $J, A$ \\
\hline \multicolumn{5}{|l|}{ Family MITROCOMIDAE } \\
\hline Cosmetirella davisi & 1983-2008; 2010 & ER & $\begin{array}{l}\text { Ramírez and Zamponi 1980; } \\
\text { Rodriguez } 2012\end{array}$ & A \\
\hline Mitrocomella frigida & 1970; 1983-2002 & ER & $\begin{array}{l}\text { Ramírez and Zamponi 1980; } \\
\text { Rodriguez } 2006\end{array}$ & A \\
\hline Mitrocomella brownei & $1983-2008 ; 2010$ & ER & $\begin{array}{l}\text { Genzano et al. 2008a; } \\
\text { Rodriguez } 2012\end{array}$ & $J, A$ \\
\hline
\end{tabular}


Table 1 Review of medusae and ctenophores from the Bahía Blanca region (Argentina) based on own data and literature data. In each case, data related to study area and type of collection from own samples are highlighted in bold while those from literature are not highlighted; when both sources overlap, data are italic (Continued)

\begin{tabular}{|c|c|c|c|c|}
\hline Halopsis ocellata ${ }^{a}$ & 2015 & MH & This study & A \\
\hline \multicolumn{5}{|l|}{ Subclass TRACHYLINAE } \\
\hline \multicolumn{5}{|l|}{ Order LIMNOMEDUSAE } \\
\hline \multicolumn{5}{|l|}{ Family OLINDIIDAE } \\
\hline Aglauropsis kawari & 1983-2008; 2015 & ER-MH & Genzano et al. 2008a; This study & $A, \mathbf{J}$ \\
\hline Gossea brachymera & $1982-1984 ; 2013-2014$ & $B B E-$ ER-MH & Mianzan 1986a; This study & na; $\mathbf{J}, \mathbf{A}$ \\
\hline Olindias sambaquiensis & $1981-1984 ; 2013-2014$ & $B B E-E R-M H$ & $\begin{array}{l}\text { Mianzan 1986a; Zamponi and Mianzan } \\
\text { 1985; Mianzan 1989c; Macchi et al. 1995; } \\
\text { Chiaverano et al. 2004; Chiaverano \& Mianzan } \\
\text { 2001; Rodriguez 2012; This study }\end{array}$ & $J, A$ \\
\hline \multicolumn{5}{|l|}{ Order TRACHYMEDUSAE } \\
\hline \multicolumn{5}{|l|}{ Family GERYONIIDAE } \\
\hline Liriope tetraphylla & 1983; 1987-1988; 1992-2002; 2013-2014 & BBE-ER-MH & Gaitán 2004; Rodriguez 2012; This study & $J, A$ \\
\hline \multicolumn{5}{|l|}{ Family HALICREATIDAE } \\
\hline Halitrephes maasi & 1970 & ER & Ramírez and Zamponi 1980 & A \\
\hline \multicolumn{5}{|l|}{ Class SCYPHOZOA } \\
\hline \multicolumn{5}{|l|}{ Subclass DISCOMEDUSAE } \\
\hline \multicolumn{5}{|l|}{ Order SEMAEOSTOMEAE } \\
\hline \multicolumn{5}{|l|}{ Family CYANEIDAE } \\
\hline Drymonema gorgo & 1982-1984; 2008; 2012 & $B B E-M H$ & Mianzan 1986a; Mianzan 1989a, b; This study & $j^{b}$ \\
\hline \multicolumn{5}{|l|}{ Family PELAGIIDAE } \\
\hline Chrysaora lactea & 1982-1984; 2013-2014 & $B B E-$ ER-MH & Mianzan 1986a; Mianzan 1989a, b; This study & $E, J, A$ \\
\hline \multicolumn{5}{|l|}{ Family ULMARIDAE } \\
\hline Aurelia aurita & 1982-1984; 2008; 2013 & BBE-MH & Mianzan 1986a; Mianzan 1989a, b; This study & $E, J, A$ \\
\hline \multicolumn{5}{|l|}{ Phylum CTENOPHORA } \\
\hline \multicolumn{5}{|l|}{ Class TENTACULATA } \\
\hline \multicolumn{5}{|l|}{ Subclass CYCLOCOELA } \\
\hline \multicolumn{5}{|l|}{ Order LOBATA } \\
\hline \multicolumn{5}{|l|}{ Family BOLINOPSIDAE } \\
\hline Mnemiopsis leidyi & 1982-1984; 1990; 2013-2014 & $B B E-E R-\mathbf{M H}$ & $\begin{array}{l}\text { Mianzan and Sabatini 1985; Mianzan } \\
\text { 1986a; Hoffmeyer } 1990 \\
\text { (as Mnemiopsis mccrady); This study }\end{array}$ & $J, A$ \\
\hline \multicolumn{5}{|l|}{ Subclass TYPHLOCOELA } \\
\hline \multicolumn{5}{|l|}{ Order CYDIPPIDA } \\
\hline \multicolumn{5}{|l|}{ Family PLEUROBRACHIIDAE } \\
\hline Pleurobrachia pileus & 1979-1981; 2013-2014 & $B B E-E \mathbf{R}-\mathbf{M H}$ & Hoffmeyer 1983; This study & na; J, A \\
\hline \multicolumn{5}{|l|}{ Class NUDA } \\
\hline \multicolumn{5}{|l|}{ Order BEROIDA } \\
\hline \multicolumn{5}{|l|}{ Family BEROIDAE } \\
\hline Beroe ovata & $1982-1984 ; 2013-2014$ & $B B E-E R-\mathbf{M H}$ & Mianzan 1986a, b; This study & $J, A$ \\
\hline
\end{tabular}

Abbreviations: BBE Bahía Blanca Estuary, MH Monte Hermoso, ER El Rincón

$E$ ephyrae, $H$ hydroids, $J$ juveniles, $A$ adults, $A c$ actinula larvae

na not available

a first record for the region

b material provided by Prof. Verónica Arias and storaged at Cátedra de Zoología de Invertebrados I, Universidad Nacional del Sur, Bahía Blanca, Argentina

' material provided by Alberto Conte and storaged at the Instituto Argentino de Oceanografía, Bahía Blanca, Argentina

\section{Amphinema dinema Péron and Lesueur 1810}

Umbrella up to $4 \mathrm{~mm}$ wide and $6 \mathrm{~mm}$ high with considerable conical, solid, apical projection, jelly of uniform thickness around top. Four undivided radial canals.
Manubrium with broad base, cross-like in section, flaskshaped, almost as long as bell cavity. Mouth with four prominent, recurved lips. With eight simple adradial gonads, smooth, on manubrium wall only. Two perradial, 
hollow, marginal tentacles with large elongated conical basal bulbs; bulbs without ocelli. With 14-24 small marginal warts (Bouillon 1999) (Fig. 2 B1-2).

\section{Aequorea forskalea Péron and Lesueur 1810}

Flat umbrella, 14-32 $\mathrm{mm}$ in diameter. Short manubrium, mouth large, about half the diameter of umbrella. Numerous radial canals (usually 60-80, sometimes fewer, and up to 160). Tentacles with elongate conical bulbs, generally less numerous than radial canals but varying from half to the same number of them; 5-10 statocysts between successive radial canals. Gonads along almost the entire length of the radial canals (Nagata et al. 2014) (Fig. 2 C1-3).

\section{Clytia lomae Torrey 1909}

Umbrella $9-12 \mathrm{~mm}$ in diameter, about 4 times broader than high, thin. Gonads narrow, elongated along less than $1 / 2$ of the distal part of radial canals; about 32 tentacles and some young bulbs. Manubrium short, cruciform; mouth with 4 slightly frilled lips; bulbs elongated; 1 (rarely 2) statocysts between successive tentacles (Bouillon 1999). Smaller medusae (umbrella 3-5 mm wide) have been observed in Argentine waters (Rodriguez 2012; this study) (Fig. 2 D1-2).

\section{Halopsis ocellata Agassiz 1865}

Umbrella $50-65 \mathrm{~mm}$ in diameter, about 4 times as wide as high, watch-glass-shaped; mesoglea thick toward centre; manubrium broad, flat, $1 / 5$ of bell diameter, circular to star-shaped in outline; mouth with 4 fairly short lips; $12-16$ radial canals in 4 groups branching usually within outline of manubrium; gonads linear, about $2 / 3$ of radial canals; up to 450 marginal tentacles; 1 marginal cirrus between successive tentacles; about 80 statocysts (Bouillon 1999). Smaller medusae (umbrella up to $28 \mathrm{~mm}$ in diameter) have been observed in Argentine waters (Rodriguez 2012; this study) (Fig. 2 E1-2).

\section{Discussion}

Our study provides the first compiled list of medusae and ctenophores species of the Bahía Blanca region, adding five hydromedusae species that had not been previously reported for the area. We found a high richness of hydromedusae species compared to values reported along the temperate Southwestern Atlantic platform (Genzano et al. 2008a; Rodriguez 2012). Based on an exhaustive sampling carried out across the neritic region from $33^{\circ}$ to $55^{\circ} \mathrm{S}$, over 20 years, Genzano et al. (2008a) recognized 71 hydromedusae species. Our study area covers less than $3 \%$ of the area covered by Genzano et al. (2008a), but we found $32.4 \%$ of the total number of hydromedusae species detected by these authors, a disproportionally large richness for the small area considered.

Taking into account the transitional location of our study area and the hydromedusae faunal list by Rodriguez (2012), we found species that equally represent both the Rionegrin and Uruguayan biogeographic districts. According to Balech and Ehrlich (2008), the Argentine Province is essentially neritic, characterized by a marked biological heterogeneity due to the mix of subtropical and subantarctic waters. This combination of subtropical and subantartic elements also determines a low level of endemism for organisms in this region. The fundamentally neritic character of the Argentine Province is further reflected in the dominance of meroplanktonic species in the Bahía Blanca region (see Bouillon et al. 2006). Among hydromedusae, the meroplanktonic Leptomedusae showed the highest genus diversity followed by Anthomedusae, and only three species of hydromedusae considered endemic to the southwestern Atlantic were observed (Mianzan 1989c; Genzano et al. 2008a).

The species observed for the first time in the study area also belong to the orders Leptomedusae and Anthomedusae. Halitiara formosa, A. dinema and C. lomae were previously reported in the Argentine Sea south and north of our study area, while $H$. ocellata and A. forskalea were reported in austral waters (from $51^{\circ}$ to $54^{\circ} 50^{\prime} \mathrm{S}$ and from $43^{\circ}$ to $53^{\circ} \mathrm{S}$, respectively). This later species was reported in Patagonian waters and there is only one record northward from our study area within the Argentine Sea $\left(37^{\circ} 40^{\prime} \mathrm{S}-56^{\circ} 02^{\prime} \mathrm{W}\right)$ (Genzano et al. 2008a). The underlying causes of the massive occurrences of $A$. forskalea observed in MH during January 2014 and February 2016 are still unresolved. We hypothesize that changes in currents and wind patterns might have produced a recurrent advection of large numbers of individuals, but further studies are required to understand the origin of these mass occurrences. However it has to be also considered that jellyfish research in the study area has been neglected over the past 20 years, and the increasing sampling effort on gelatinous zooplankton throughout the last 5 years increased the proportion of findings related to gelatinous species.

Chrysaora lactea, A. aurita and D. gorgo were the only scyphozoans found in the study area (Mianzan 1989a, b; Schiariti et al. 2016; this study). Although we did not find $A$. aurita ephyrae in our samples, recently released ephyrae of this species were reported by Mianzan (1989a) who suggested the use of this coastal area as a reproduction site. Regarding C. lactea even though medusae are rather common and widespread, ephyrae have been rarely observed in plankton samples elsewhere (Mianzan 1989a, 1989b; Tronolone et al. 2002). In our samples, however, ephyrae of C. lactea were frequently found, which supports the suggestion by Mianzan 

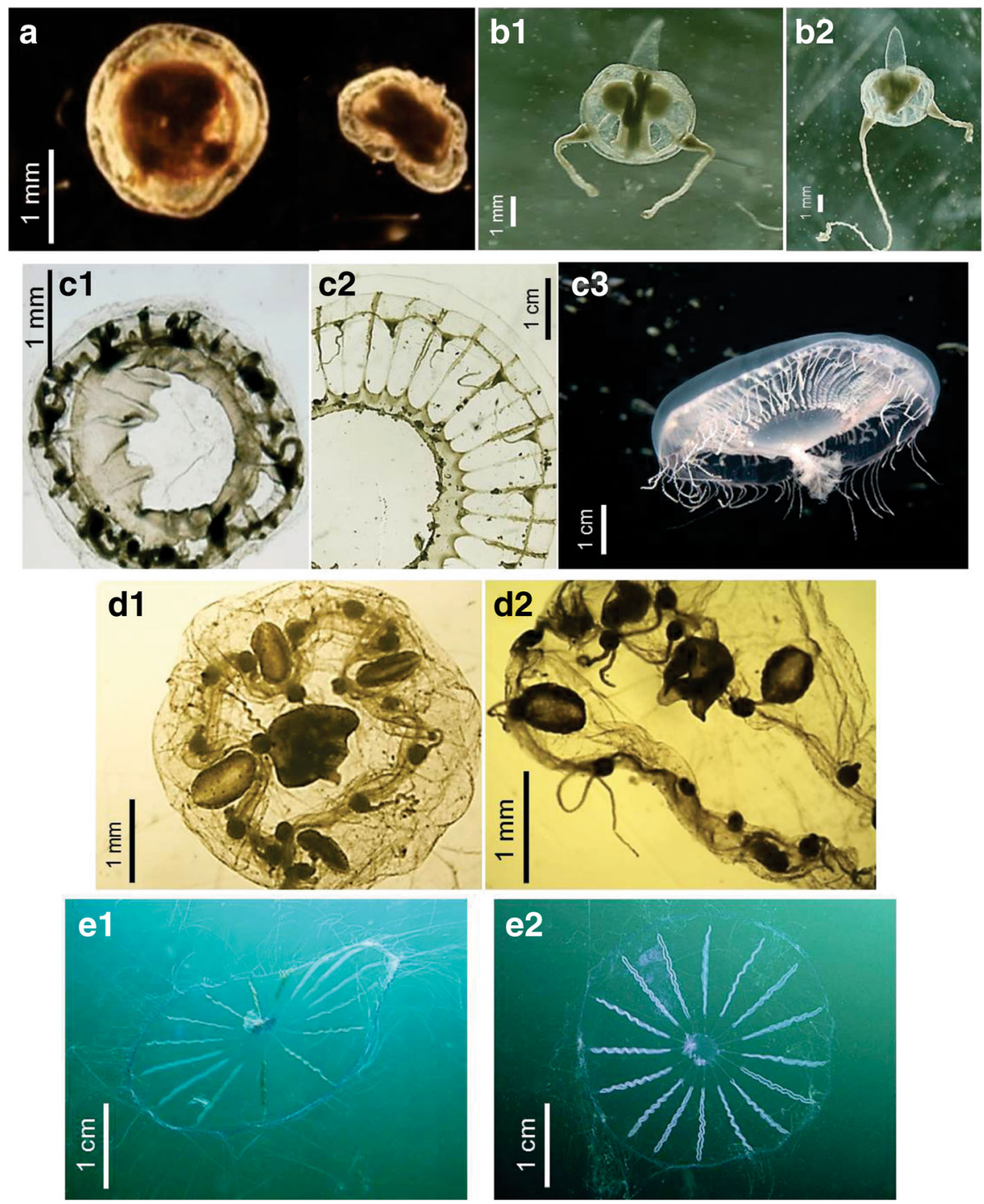

Fig. 2 Photographs of the five hydromedusae species firstly observed in the study area. A) Adults of H. formosa, B1-2) Adults of A. dinema, C1) juvenile and (2-3) adults of A. forskalea, D1-2) adults of C. lomae, E1-2) adults of H. ocellata. C3 and E1-2 reproduced with the permission of Kåre Telnes (www.seawater.no)

(1989a) about the reproduction area for these scyphozoans. Polyps of C. lactea have never been found in nature (Morandini et al. 2004). Potential substrata for polyp settlement include docks, harbors, support structures of industries, dredged material storage piles, buoys, fouling fauna, native vegetation, rocky, muddy and sandy bottoms (Miyake et al. 2002; Morandini et al. 2004; Lucas et al. 2012), all of them available in the study area. Future research should include benthic surveys to explore the presence of benthic stages, and their association with natural and human-made substrates. Finally, the occurrence of $D$. gorgo is a rare event that reconfirms its geographical distributional range for these latitudes (Mianzan 1989a, 1989b). Information on its ecology and distribution is very scarce due to its sporadic occurrence and the few specimens available for study (Williams et al. 2001; Bayha and Dawson 2010).

Coastal ctenophores are a major macroplanktonic group in the Southwestern Atlantic (Mianzan 1999), that may dominate zooplankton abundance and biomass (Mianzan et al. 1996; Mianzan and Guerrero 2000). In our study area, aggregations of ctenophores were observed at different times and sites (Hoffmeyer 1983; Mianzan and Sabatini 1985; Mianzan 1986a; Hoffmeyer 1990, this study). The occurrences of $M$. leidyi, B. ovata, and P. pileus in our samples are in agreement with findings by Mianzan and Sabatini (1985) and Mianzan (1986a). 
Regarding the three species of public health concern, $O$. sambaquiensis has been long considered the most problematic species in terms of its health consequences, as well as its detrimental effects on touristic development (Mianzan et al. 2001). It causes severe skin damage and pain (Kokelj et al. 1993). Adults range in size from 6 to $10 \mathrm{~cm}$ (Nagata et al. 2014) although specimens up to $21 \mathrm{~cm}$ were observed in our study area (Mianzan 1986a). This species has a clear seasonal pattern of high-density aggregations during the warmest months (Macchi et al. 1995; Mianzan and Ramírez 1996), and were reported in the area from October to April (Mianzan 1986a). In spite of its presence year after year, the asexual polyp phase of $O$. sambaquinsis remains unidentified, and little is known about its population dynamic and reproduction (Macchi et al. 1995; Chiaverano et al. 2004). Regarding our samples, immature stages were expected to be found in late spring, as well as adults in summer. Nevertheless, juveniles did not appear and observations of adults reduced to sporadic occurrence in the area. This is in accordance with the unusual trend observed since 2013, characterized by a disappearance of the high-density aggregations usually observed (Brendel AS, Dutto MS, Menéndez MC, Huamantinco Cisneros MA, Piccolo MC: Wind pattern variation in a SW Atlantic beach: An explanation for changes in the coastal occurrence of the medusa Olindias sambaquiensis, submitted). The large amounts of L. tetraphylla observed in summer, since 2014, have also raised concern. These aggregations which can cause severe pruritus and strong itching sensation in sensitive areas of human skin conform a locally-known phenomenon called "tapioca", which was well documented on northern beaches in Argentina and Uruguay (Mianzan et al. 2000), but never reported in this geographic area or further south. Finally, Chrysaora lactea was the last stinging species found in the study area. It is one of the most common blooming scyphozoan along the entire South Western Atlantic coast (Mianzan and Cornelius 1999; Migotto et al. 2002; Schiariti et al. 2016). This species can cause mild to moderate local pain and burning sensation. Although less common, erythema and edema forming lesions were also reported (Marques et al. 2014).

The background list provided lays the foundation for the development of further investigations on gelatinous zooplankton in this highly relevant economic and biological coastal area. Benthic surveys are required to confirm the occurrence of polyps and to provide potential valuable information on the biology of the gelatinous species (e.g. life cycle) inhabiting this geographic region.

\section{Acknowledgements}

This work was supported by Agencia Nacional de Promoción Científica y Tecnológica (PICT 2011-2096 to M.S. Hoffmeyer, PICT 2013-1773 to A. Schiariti, and PICT 2012-2071 to P.D. Pratolongo), Secretaría General de Ciencia y Tecnología, Universidad Nacional del Sur (PGI 24 B/236), Universidad Nacional de Mar del Plata
(EXA 734/15 to G.N. Genzano), and Consejo Nacional de Ciencia y Tecnología of Argentina (PIP 0152 to G.N. Genzano and PIP 2013-00615 to A. Schiariti). We thank greatly to A. Conte, E. Redondo, E. Contardi, C. Bernárdez, and J. Albrizio, to Cámara de Pescadores de Monte Hermoso and Pehuen Có, especially to E. Flores, and to all the colleagues which help and assist during samplings and laboratory activities: A. Berasategui, E. Nahuelhual, R. Uibrig, D. Muro Schenfelt, M. Garcia, J. Chazarreta, C. López Abbate, C. Menéndez, A. Delgado, V. Guinder, F. Thomsen, R. Elicer, M. Tártara, E. Dos Santos, L. Diaz Briz, C. Rodriguez, and A. Puente Tapia. The collaboration with material of A. Conte, V. Arias and D. Tanzola is also much appreciated. Thanks are also due to A. Migotto for providing photographs and W. Melo for drawing the map. We appreciate the thorough review of the manuscript by Dr. M. Thiel and two anonymous referees.

\section{Authors' contributions}

GNG, AS, MSH and PDP contributed to draft the manuscript. MSD wrote the manuscript. GNG and AS participated in the identification of the species. JL contributed with biological material. All authors read and approved the final manuscript.

Competing interests

The authors declare that they have no competing interests.

\section{Publisher's Note}

Springer Nature remains neutral with regard to jurisdictional claims in published maps and institutional affiliations.

\section{Author details}

${ }^{1}$ Consejo Nacional de Investigaciones Científicas y Técnicas (CONICET), Av. Rivadavia 1917, C1033AAJ Ciudad Autónoma de Buenos Aires, Argentina. ${ }^{2}$ Instituto Argentino de Oceanografía (IADO-CONICET/UNS), Área

Oceanografía Biológica, La Carrindanga km 7.5, B8000FWB Bahía Blanca, Argentina. ${ }^{3}$ Instituto de Investigaciones Marinas y Costeras (IIMyC), Funes 3350, B7602AYL Mar del Plata, Argentina. ${ }^{4}$ Departamento de Ciencias Marinas, Facultad de Ciencias Exactas y Naturales, Universidad Nacional de Mar del Plata (UNMdP), Funes 3350, B7602AYL Mar del Plata, Argentina. ${ }^{5}$ Instituto Nacional de Investigación y Desarrollo Pesquero (INIDEP), Paseo Victoria Ocampo № 1, Escollera Norte, B7602HSA Mar del Plata, Argentina. ${ }^{6}$ Museo Municipal de Ciencias Naturales de Monte Hermoso, N. Fossatty (ex Rio Paraná) N 250, 8153 Balneario Monte Hermoso, Buenos Aires, Argentina. ${ }^{7}$ Universidad Nacional del Sur (UNS), Bahía Blanca, Argentina. ${ }^{8}$ Facultad Regional Bahía Blanca, Universidad Tecnológica Nacional (UTN), 11 de Abril 461, B8000LMI Bahía Blanca, Argentina. ${ }^{9}$ Departamento de Biología, Bioquímica y Farmacia, UNS, San Juan 670, B8000DIC Bahía Blanca, Argentina.

Received: 17 September 2015 Accepted: 17 January 2017

Published online: 12 May 2017

\section{References}

Acha EM, Mianzan HW, Guerrero RA, Favero M, Bava J. Marine fronts at the continental shelves of austral South America: Physical and ecological processes. J Mar Syst. 2004;44:83-105.

Acha EM, Orduna M, Rodrigues K, Militelli MI, Braverman M. Caracterización de la zona de "El Rincón" (provincia de Buenos Aires) como área de reproducción de peces costeros. Revista de Investigación y Desarrollo Pesquero. 2012;21:31-43.

Agassiz A. Halopsis ocellata. Proc Boston Soc Nat Hist. 1865;9:219-20.

Balech E, Ehrlich MD. Esquema Biogeográfico del Mar Argentino. Revista de Investigación y Desarrollo Pesquero. 2008;19:45-75.

Bastida RO, Torti MR. Estudio preliminar sobre las incrustaciones biológicas de Puerto Belgrano. LEMIT-Anales. 1971;3:47-75.

Bastida RO, L'Hoste S, Spivak E, Adabbo H. Las incrustaciones biológicas de Puerto Belgrano. I. Estudio de la fijación sobre paneles mensuales, período 1971/72. Corrosión y Protección. 1977;8:1-23.

Bayha KM, Dawson MN. New Family of Allomorphic Jellyfishes, Drymonematidae (Scyphozoa, Discomedusae), Emphasizes Evolution in the Functional Morphology and Trophic Ecology of Gelatinous Zooplankton. Biol Bull. 2010; 219:249-67.

Blanco O. Enumeración sistemática y distribución geográfica preliminar de los Hidroides de la República Argentina. Suborden Athecata (Gymnoblastea, Anthomedusae), Thecata (Calyptoblastea, Leptomedusae) y Limnomedusae. Revista del Museo de La Plata. 1994;14:181-216. 
Bouillon J. Hydromedusae. In: Boltovskoy D, editor. South Atlantic Zooplankton. Leiden: Backhuys Publishers; 1999. p. 385-465.

Bouillon J, Gravili C, Pagès F, Gili JM, Boero F. An introduction to Hydrozoa. Memoires du Museum National d'Histoire Naturelle. Publications Scientifiques, vol. 194. 2006. p. 591

Carcedo MC, Fiori SM, Piccolo MC, López Abbate MC, Bremec CS. Variations in macrobenthic community structure in relation to changing environmental conditions in sandy beaches of Argentina. Estuar Coast Shelf Sci. 2015;166:56-64.

Carozza C, Fernández Aráoz NC. Análisis de la actividad de la flota en el área de "El Rincón" dirigida al variado costero durante el período 2000-2008 y situación de los principales recursos pesqueros. INIDEP Informe técnico oficial N 23/09. 2009.

Chiaverano L, Mianzan H. Dinámica y estructura poblacional de Olindias sambaquiensis, Muller, 1861 (Limnomedusae, Olindiidae) durante su fase sexual en la zona de Bahía Blanca (Buenos Aires, Argentina). San Andrés Isla: IX Congreso Latinoamericano sobre Ciencias del Mar; 2001.

Chiaverano L, Mianzan H, Ramírez F. Gonad development and somatic growth patterns of Olindias sambaquiensis (Limnomedusae, Olindiidae). Hydrobiologia. 2004;530-531:373-81.

Delgado AL, Loisel H, Jamet C, Vantrepotte V, Perillo GME, Piccolo MC. Seasonal and inter-annual analysis of chlorophyll-a and inherent optical properties from satellite observations in the inner and mid-shelves of the south of Buenos Aires Province (Argentina). Remote Sens. 2015;7:11821-47.

Delgado AL, Menéndez MC, Piccolo MC, and Perillo GME. Hydrography of the inner continental shelf 'along the southwest Buenos Aires Province, Argentina: Influence of an estuarine plume on coastal waters. J Coastal Res. 2016. doi: http://dx.doi.org/10.2112/JCOASTRES-D-16-00064.1.

Delhey K, Petracci PF. Aves marinas y costeras. In: Piccolo MC, Hoffmeyer MS, editors. Ecosistema del Estuario de Bahía Blanca. Bahía Blanca: EdiUNS; 2004. p. 203-20.

Fewkes JW. Notes on acalephs from the Tortugas, with a description of new genera and species. In: Agassiz A, editor. Explorations of the surface fauna of the Gulf Stream, under the auspices of the U.S. Coast Survey. Bulletin of the Museum of comparative Zoölogy of Harvard College, vol. 9. 1882. p. 251-89.

Gaitán EN. Distribución, abundancia y estacionalidad de Liriope tetraphylla (Hidromedusa, Trachymedusae) en el Océano Atlántico Sudoccidental y su rol ecológico en el estuario del Río de la Plata. MSc thesis. Mar del Plata: Universidad Nacional de Mar del Plata; 2004.

Genzano G, Mianzan H, Bouillon J. Hydromedusae (Cnidaria: Hydrozoa) from the temperate southwestern Atlantic Ocean: a review. Zootaxa. 2008a;1750:1-18.

Genzano GN, Mianzan HW, Diaz BL, Rodriguez CS. On the occurrence of Obelia medusa bloom and empirical evidence of an unusual Obelia and Amphisbetia hydroids shoreline massive accumulations. Lat Am J Aquat Res. 2008b;36:301-7.

Genzano GN, Giberto D, Schejter L, Bremec C, Meretta P. Hydroid assemblages from the Southwestern Atlantic Ocean (34-42 S). Mar Ecol. 2009a;30:33-46.

Genzano GN, Rodriguez C, Pastorino G, Mianzan HW. The hydroid and medusa of Corymorpha januarii in temperate waters of the Southwestern Atlantic Ocean. Bull Mar Sci. 2009b;84:229-35.

Guinder VA, Popovich CA, Molinero JC, Marcovecchio J. Phytoplankton summer bloom dynamics in the Bahía Blanca Estuary in relation to changing environmental conditions. Cont Shelf Res. 2013:52:150-8.

Hoffmeyer MS. Zooplancton del área interna de Bahía Blanca (Buenos Aires Argentina). I- Composición faunística. Hist Nat. 1983:3:73-94.

Hoffmeyer MS. Algunas observaciones sobre la alimentación de Mnemiopsis mccradyi Mayer (Ctenophora-Lobata). Iheringia Serie Zoologia. 1990;70:55-65.

Hoffmeyer MS, Barría de Cao MS. Zooplankton assemblage from a tidal channel in the Bahía Blanca Estuary. Braz J Oceanogr. 2007;55:97-107.

Hoffmeyer MS, Mianzan HW. Macrozooplancton del estuario de Bahía Blanca y aguas adyacentes. In: Piccolo MC, Hoffmeyer MS, editors. Ecosistema del Estuario de Bahía Blanca. Bahía Blanca: EdiUNS; 2004. p. 143-51.

Hoffmeyer MS, Menéndez MC, Biancalana F, Nizovoy AM, Torres ER. Ichthyoplankton spatial pattern in the inner shelf off Bahía Blanca Estuary, SW Atlantic Ocean. Estuar Coast Shelf Sci. 2009;84:383-92.

Kokelj F, Mianzan H, Avian M, Burnett JW. Dermatitits due to Olindias sambaquiensis: a case report. Cutis. 1993;51:339-42.

Kramp PL. Synopsis of the medusa of the world. J Mar Biol Assoc U K. 1961:40:1-469.

Lucas CH, Graham WM, Widmer C. Jellyfish life histories: role of polyps in forming and maintaining scyphomedusa populations. Adv Mar Biol. 2012;63:133-96.

Macchi G, Mianzan H, Cristiansen H, Ramírez F. Histology of the gonadal cycle of the stinging hydromedusa Olindias sambaquiensis, Muller, 1861 at Blanca Bay, Argentina. Bolletino della Societa Adriatica di Scienze. 1995;76:59-68.
Marques AC, Haddad Jr V, Rodrigo L, Marques-da-Silva E, Morandini AC. Jellyfish (Chrysaora lactea, Cnidaria, Semaeostomeae) aggregations in southern Brazil and consequences of stings in humans. Lat Am J Aquat Res. 2014;42:1192-9. Mayer A. Medusae of the world. Hydromedusae. 1910;1:1-230.

Menéndez MC, Fernández Severini MD, Buzzi NS, Piccolo MC, Perillo GME. Assessment of surf zone environmental variables in a southwestern Atlantic sandy beach (Monte Hermoso, Argentina). Environ Monit Assess. 2016;188: 495-507. doi:10.1007/s10661-016-5495-9.

Mianzan HW. Estudio sistemático y bioecológico de algunas medusas Scyphozoa de la región subantártica. Phd thesis. La Plata: Universidad Nacional de La Plata; 1986a.

Mianzan HW. Beroe ovata en aguas de la Bahía Blanca, Argentina (Ctenophora). Spheniscus. 1986b;2:29-32.

Mianzan HW. Las medusas Scyphozoa de la Bahía Blanca. Boletim do Instituto Oceanografico São Paulo. 1989a;37:29-32.

Mianzan HW. Sistemática y zoogregrafía de Scyphomedusae en aguas neríticas argentinas. Investigaciones Marinas CICIMAR. 1989b;4:15-34.

Mianzan HW. Distribución de Olindias sambaquiesis Müller, 1861 (Hydrozoa, Limnomedusae) en el Atlántico Sudoccidental. Iheringia Série Zoologia. 1989c;69:155-7.

Mianzan HW. Ctenophora. In: Boltovskoy D, editor. South Atlantic Zooplankton. Leiden: Blackhuys Publishers; 1999. p. 561-73.

Mianzan HW, Cornelius PFS. Cubomedusae and Scyphomedusae. In: Boltovskoy D, editor. South Atlantic Zooplankton. Leiden: Backhuys Publishers; 1999. p. 513-59.

Mianzan HW, Guerrero RA. Environmental patterns and biomass distribution of gelatinous macrozooplankton. Three study cases in the South-Western Atlantic Ocean. Sci Mar. 2000;64:215-24.

Mianzan HW, Ramírez FC. Olindias sambaquiensis stings in the South West Atlantic. In: Williamson JAH, Fenner PJ, Burnett JW, Rifkin JF, editors. Venomous and poisonous marine animals: a medical and biological handbook. Brisbane: University of New South Wales Press; 1996. p. 206-8.

Mianzan HW, Sabatini M. Estudio preliminar sobre distribución y abundancia de Mnemiopsis maccradyi en el estuario de Bahía Blanca (Ctenophora). Spheniscus. 1985;1:53-68.

Mianzan HW, Zamponi MO. Estudio bioecológico de Olindias sambaquiensis Müller, 1861 (Limnomedusae, Olindiidae) en el área de Monte Hermoso. II. Factores meteorológicos que influyen en su aparición. Iheringia Série Miscelanea. 1988;2:63-8.

Mianzan HW, Mari N, Prenski B, Sanchez F. Fish predation on neritic ctenophores from the Argentine continental shelf: A neglected food resource? Fish Res. 1996:27:69-79.

Mianzan HW, Sorarrain D, Burnett JW, Lutz LL. Mucocutaneous junctional and flexural paresthesias caused by the holoplanktonic trachymedusae Liriope tetraphylla. Dermatology. 2000;201:46-8.

Mianzan HW, Fenner PJ, Cornelius PFS, Ramírez C. Vinegar as disarming agent to prevent further discharge of the nematocysts of the stinging hydromedusa Olindias sambaquiensis. Cutis. 2001;6:45-8.

Migotto AE, Marques AC, Morandini AC, da Silveira FL. Checklist of the Cnidaria Medusozoa of Brazil. Biota Neotropica. 2002;2:1-31.

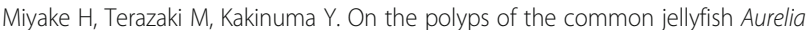
aurita in Kagoshima Bay. J Oceanogr. 2002;58:451-9.

Morandini AC, da Silveira FL, Jarms G. The life cycle of Chrysaora lactea Eschscholtz, 1829 (Cnidaria, Scyphozoa) with notes on the scyphistoma stage of three other species. Hydrobiologia. 2004;530:347-54.

Nagata RM, Nogueira M, Haddad MA. Faunistic survey of Hydromedusae (Cnidaria, Medusozoa) from the coast of Paraná State, Southern Brazil. Zootaxa. 2014;3768:291-326.

Negrin VL, Botté SE, Pratolongo PD, González TG, Marcovecchio JE. Ecological processes and biogeochemical cycling in salt marshes: synthesis of studies in the Bahía Blanca estuary (Argentina). Hydrobiologia. 2016;774:217-35.

Péron F, Lesueur CA. Tableau des caractères génériques et spécifiques de toutes les espèces de méduses connues jusqu'à ce jour. Annales du Muséum National d'histoire Naturelle de Paris. 1810;14:325-66.

Pizarro N, Piccolo MC. Socio-economic issues in the Bahía Blanca Estuary. In: Neves R, Baretta J, Mateus M, editors. Perspectives on integrated coastal zone management in South America. Lisbon: IST Press; 2008. p. 287-300.

Popovich CE, Marcovecchio JE. Spatial and temporal variability of phytoplankton and environmental factors in a temperate estuary of South America (Atlantic coast, Argentina). Cont Shelf Res. 2008;28:236-44.

Pratolongo P, Mazzon C, Zapperi G, Piovan MJ, Brinson MM. Land cover changes in tidal salt marshes of the Bahía Blanca estuary (Argentina) during the past 40 years. Estuar Coast Shelf Sci. 2013;133:23-31. 
Ramírez FC, Zamponi MO. Medusas de la plataforma bonaerense y sectores adyacentes. Physis. 1980;39:33-48.

Ramírez FC, Zamponi MO. Hydromedusae. In: Boltovskoy D, editor. Atlas del Zooplancton del Atlántico Sudoccidental y Métodos de Trabajo con el Zooplancton Marino. Mar del Plata: Publicaciones Especiales de INIDEP; 1981. p. 443-69.

Rodriguez CS. Distribución, abundancia y estacionalidad de Mitrocomella frigida y Eucheilota ventricularis (Hydrozoa, Leptomedusae) en el Atlántico Sudoccidental $\left(33-55^{\circ} \mathrm{S}\right)$. MSc thesis. Mar del Plata: Universidad Nacional de Mar del Plata; 2006.

Rodriguez C. Hidromedusas del Atlántico Sudoccidental: biodiversidad y patrones de distribución. PhD thesis. Mar del Plata: Universidad Nacional de Mar del Plata; 2012.

Rodriguez C, Genzano G, Mianzan H. First record of Eutonina scintillans Bigelow, 1909 (Hydrozoa: Leptomedusae: Eirenidae) in temperate waters of the southwestern Atlantic Ocean. Investig Mar. 2007:35:135-8.

Rodriguez C, Miranda TP, Marques AC, Mianzan H, Genzano G. The genus Hybocodon (Cnidaria, Hydrozoa) in the southwestern Atlantic Ocean, with a revision of Hybocodon species recorded in the area. Zootaxa. 2012;3523:39-48. Schiariti A, Dutto MS, Morandini AC. Diversity and spatial distribution of Scyphomedusae and Cubomedusae from Argentina and Uruguay. Barcelona: 5th International Jellyfish Bloom Symposium, May 30-June 3 2016; 2016. p. 152. Torrey HB. The Leptomedusae of the San Diego region. Univ Calif Publ Zool. 1909;6:11-31.

Tronolone VB, Morandini AC, Migotto AE. On the occurrence of scyphozoan ephyrae (Cnidaria, Scyphozoa, Semaeostomeae and Rhizostomeae) in the southeastern brazilian coast. Biota Neotropica. 2002;2:1-18.

Vaquero M del C, Rodríguez C, Trellini M, de Bulnes Cernadas M, Marcilese J. El turismo residenciado en Monte Hermoso. In: Proceedings of IV Jornadas interdisciplinarias del sudoeste bonaerense, Universidad Nacional del Sur, 7-9 September 2006. Bahía Blanca: Cuestiones políticas, socioculturales y económicas en el sudoeste bonaerense; 2007. p. 201-6.

Williams Jr EH, Bunkley-Williams L, Lilyestrom CG, Larson RJ, Engstrom NA, OrtizCorps EAR, Timber JH. A population explosion of the rare tropical/subtropical purple sea mane, Drymonema dalmatinum, around Puerto Rico in the summer and fall of 1999. Caribb J Sci. 2001;37:127-30.

Zamponi MO, Mianzan HW. La mecánica de captura y alimentación de Olindias sambaquiensis Müller, 1861 (Limnomedusae) en el medio natural y en condiciones experimentales. Hist Nat. 1985;5:269-78.

\section{Submit your next manuscript to BioMed Central and we will help you at every step:}

- We accept pre-submission inquiries

- Our selector tool helps you to find the most relevant journal

- We provide round the clock customer support

- Convenient online submission

- Thorough peer review

- Inclusion in PubMed and all major indexing services

- Maximum visibility for your research

Submit your manuscript at wuw biomedcentral.com/submit

) Biomed Central 